\title{
Very Large, Rapidly Growing Myoma during Second Trimester of Pregnancy - Outcome
}

\author{
Angel Danchev Yordanovi*, Krasimira Zhivkova Zhelyaskova² ${ }^{2}$ Ilko Ivanov Iliev ${ }^{1}$, Polina Petkova Vasileva ${ }^{3}$, \\ Nikola Kalinov Popovski ${ }^{3}$ and Momchil Denev Ivanov ${ }^{4}$ \\ ${ }^{1}$ Clinic of Gynecologic Oncology, University Hospital "Dr. Georgi Stranski"-Pleven, Bulgaria \\ ${ }^{2}$ Medical Center "Petinka Tzvetkova"-Varna, Bulgaria \\ ${ }^{3}$ Department of Obstetrics and Gynecology, Medical University, Bulgaria \\ ${ }^{4}$ MHAT "Saint Paraskeva"-Pleven, Bulgaria
}

Submission: October18, 2017; Published: October 26, 2017

*Corresponding author: Angel Danchev Yordanov, Clinic of Gynecologic Oncology, University Hospital “Dr.G. St ranski”-Pleven, Bulgaria, Email: angel.jordanov@gmail.com

\begin{abstract}
Intruduction: The leyomyoma is the most common gynaecological tumor. Uterine myomas during pregnancy occur in 2 to $10 \%$ of all cases. One tenth of those may lead to complications of the pregnancy. According to most ultrasounds studies myomas remain the same size or become smaller during pregnancy.
\end{abstract}

Case: This case report is about 34 year old woman, nullipara, in 14th week of pregnancy. Through ultrasound observation was found subserous pediculated myoma node with diameter of $20 \mathrm{~cm}$. When the pregnancy was found, the myoma was not. A median laparotomy with myomectomy was performed without any complications. On the 38th week of pregnancy a healthy, $3400 \mathrm{~g}$, full-term baby was delivered by cesarean section.

Conclusion: Though rarely, rapidly growing and very large myomas can be an indication for miomectomy during the second trimester of pregnancy. Laparotomic myomectomy should be preferred over laparoscopic myomectomy in cases of very large myomas, due to prolonged operative time, inapplicability of in-bag morcellation and related risks of dissemination of a leiomyoma or leiomyosarcoma.

Keywords: Very large myoma; Pregnancy; Myomectomy; Rapidly growing myoma

\section{Introduction}

The leiomyoma is the most common benign gynaecological tumour [1]. Uterine myomas during pregnancy occur in 2 to $10 \%$ of all cases. One tenth of those may lead to complications of the pregnancy. According to most ultrasounds studies myomas remain the same size or become smaller during pregnancy [2-4]. Estrogen and progesterone were thought to play a major role in the development and growth of myomas, but recently this theory has been questioned.

Usually myomectomy is avoided during pregnancy, but in some situations it is indicated, despite the risk of hemorrhagic complications that may require hysterectomy due to the increased vascularity [5-7]. Laparotomic myomectomy during pregnancy has been reported as a safe approach more than a hundred years ago $[8,9]$. The most common indications for myomectomy during pregnancy are acute pelvic pain that is not responsive to medical therapy, signs of red infarction or torsion of pedunculated myomas, and abdominal discomfort due to a large or rapidly growing myomas $[7,10]$.

\section{Clinical Case}

We present a 34 year old nulliparous, Caucasian woman at 14 th week of gestation. The patient was admitted in our clinic with a $20 \mathrm{~cm}$ myoma. A few months ago, before the conception, through ultrasound observation a normal gynecologycal status was found. At $5^{\text {th }}$ gestational week a normal pregnancy was detected, without any signs of myoma. At $7^{\text {th }}$ week of pregnancy a $3.5 \mathrm{~cm}$. subserous myoma was found. At $12^{\text {th }}$ week of pregnancy the ultrasound observation showed a subserous pediculated myoma on the left edge of the uterine fundus with dimensions $15 / 10.9 \mathrm{~cm}$. The analysis of the ultrasound observations showed unexpected progressive increasing of the myoma size. Because of the rapid growth and the big size a median laparotomy with myomectomy was performed. A $23 \mathrm{~cm}$ pedunculated subserosal 
myoma with an implantation base of $4 \mathrm{~cm}$ was found (Figure $1 \& 2$ ). The operation and the postoperative period take place without any complications. On the 38th week of pregnancy a healthy, 3400g, full-term, baby boy was delivered by cesarean section. Postpartum and the puerperium period had a regular course.

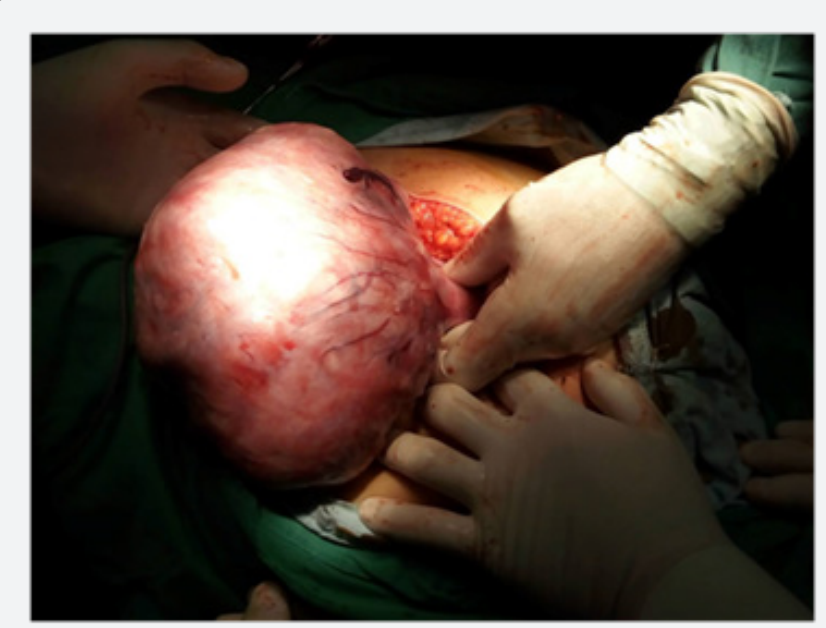

Figure 1: Intraoperative findings.

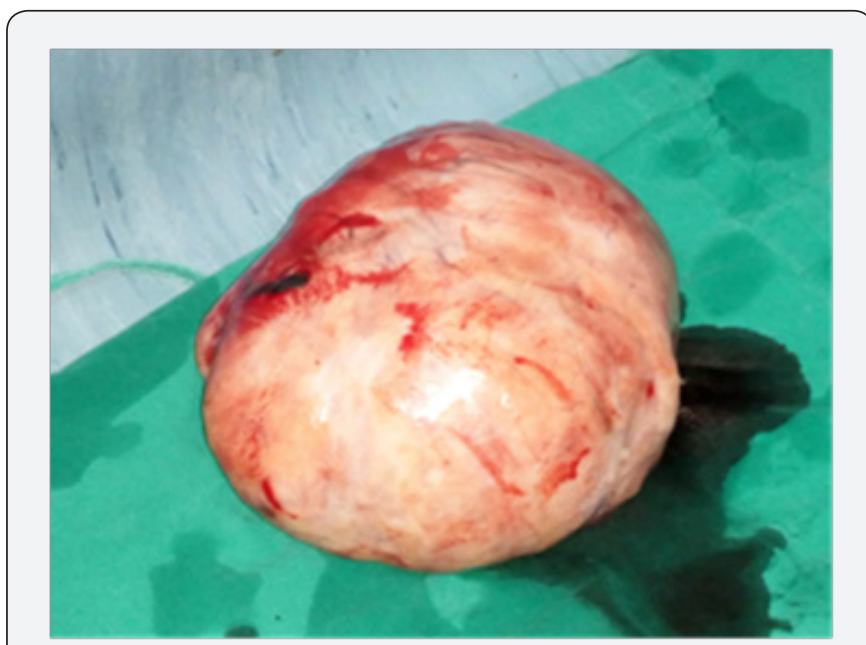

Figure 2: Myoma.

\section{Discussion}

Different outers classify myomas by size in different ways. Most agree that myoma is large when it is over $5 \mathrm{~cm}$ [11-14]. The Society of Obstetricians and Gynaecologists of Canada, classify myomas over $10 \mathrm{~cm}$. like very large [15].

Most ultrasound studies have shown that most of the fibroids during pregnancy (60\%-78\%) do not show significant changes in their volume. Out of the fibroids that did increase their volume $(22 \%$ to $32 \%)$, the growth was limited in the first trimester $[16,17]$. There is a prospective study, according to which, if a myoma increases its size during pregnancy, that increase is $12 \pm 6 \%$ of the initial size, up to a maximum of $25 \%$ [16]. A variety of factors, such as genetic and epigenetic mechanism, growth factors, cytokines and disorganization of extracellular matrix components have shown interaction with their pathogenesis [18].

How leiomyomas affect pregnancy is based on their number, size and localization. A significant part of myomas remain asymptomatic and do not require treatment, but $10 \%$ lead to complications such as: fetal growth restriction, pelvic pain, placental abruption, placenta previa / accrete, fetal deformities, dystocia, postpartum hemorrhagia [19]. Acceptable indications for myomectomy during pregnancy include intractable pain from a degenerating myoma especially if it is subserosal or pedunculated, a large or rapidly growing myoma, or any large myoma ( $>5 \mathrm{~cm}$ ) located in the lower uterine segment [12]. The outcome, both obstetric and neonatal, of women, who underwent myomectomy in pregnancy is comparable to the outcome of those, who were managed conservatively [20,21]. According to few studies, antepartum myomectomy can be safely performed in the first and second trimester of pregnancy, if indicated [2027].

There is enough scientific data about the safety of laparotomic myomectomy during pregnancy. Recently the number of case reports and studies about the possibility of performing a safe laparoscopic myomectomy during pregnancy is gradually increasing. It begins to slowly replace open surgery because of certain advantages less blood loss, diminished postoperative pain, fewer overall complications, faster recovery and significant cosmetic. However, there are also disadvantages, like the prolonged operative time because of the need of morcellation, especially time-consuming myomas larger than $10 \mathrm{~cm}[16,28]$.

Morcellation by itself has additional risks of vascular or visceral trauma, and can also lead to leiomyoma dissemination (leiomyomatosis). The possibility of a leiomyosarcoma can't be ruled out, which would lead to a sudden decrease in survivability and upstaging of the disease [16]. Some of those risks can be brought down to a minimum through the use of inbag morcellation, but when a large myoma is present and given the limited area, in cases like ours it is inapplicable. Another disadvantage of the laparoscopic myomectomy during pregnancy is the need of additional training, an experienced surgeon and specialized equipment [16].

\section{Conclusion}

Though rarely, rapidly growing and very large myomas can be an indication for myomectomy during the second trimester of pregnancy, because of the limited space for fetus development.

Laparotomic myomectomy should be preferred over laparoscopic myomectomy in cases of very large myomas, due to prolonged operative time, inapplicability of in-bag morcellation and related risks of dissemination of a leiomyoma or leiomyosarcoma. 


\section{Acknowledgement}

The publication was funded by progect BG05M20P0012.009-0031-C01.

\section{References}

1. Ryan GL, Syrop CH, Van Voorhis BJ (2005) Role, epidemiology, and natural history of benign uterine mass lesions. Clin Obstet Gynecol 48(2): 312-324.

2. Hammoud AO, Asaad R, Berman J, Treadwell MC, Blackwell S, et al (2006) Volume change of uterine myomas during pregnancy: do myomas really grow? J Minim Invasive Gynecol 13(5): 386-390.

3. Muram D, Gillieson M, Walters JH (1980) Myomas of the uterus in pregnancy: ultrasonographic follow-up. Am J Obstet Gynecol 138(1): 16-19.

4. Neiger R, Sonek JD, Croom CS, Ventolini G (2006) Pregnancy-related changes in the size of uterine leiomyomas. J Reprod Med 51(9): 671674 .

5. Yumi H (2008) Guidelines for diagnosis, treatment, and use of laparoscopy for surgical problems during pregnancy. Surg Endosc 22: 849-861.

6. Lolis DE, Kalantaridou SN, Makrydimas G, Sotiriadis A, Navrozoglou I, et al. (2003) Successful myomectomy during pregnancy. Hum Reprod 18(8): 1699-1702.

7. Fanfani F, Rossitto C, Fagotti A, Rosati P, Gallotta V, et al. (2010) Laparoscopic myomectomy at 25 weeks of pregnancy: case report. J Minim Invasive Gynecol 17(1): 91-93.

8. Evans HM (1899) A case of myomectomy for subperitoneal myoma complicating pregnancy. Br Med J 2: 1673.

9. Doran A (1906) Myomectomy during pregnancy and labour at term in an elderly primipara: with notes on similar cases. Br Med J 2(2395): 1446-1447.

10. Ardovino M, Ardovino I, Castaldi MA, Monteverde A, Colacurci N, et al. (2011) Laparoscopic myomectomy of a subserous pedunculated fibroid at 14 weeks of pregnancy: a case report. J Med Case Rep 5: 545.

11. American Association of Gynecologic Laparoscopists (AAGL): Advancing Minimally Invasive Gynecology Worldwide (2012) AAGL Practice Report: Practice Guidelines for the Diagnosis and Management of Submucous Leiomyomas. J Minim Invasive Gynecol 19(2): 152-171.

12. Joong Lee H, Norwitz ER, Shaw J (2010) Contemporary Management of Fibroids in Pregnancy. Rev Obstet Gynecol 3(1): 20-27.

13. Marvelos D, Ben-Nagi J, Holand T, Hoo W, Naftalin J, et al. (2010) The natural history of fibroids. Ultrasound Obstet Gynecol 35(2): 238-242.
14. Kanaoka Y, Hirai K, Ishiko O (2005) Microwave endometrial ablation for menorrhagia caused by large submucous myomas. J Obstet Gynaecol Res 31(6): 565-570.

15. Vilos G, Allaire C, Laberge Ph, Leyland N (2015) The Management of Uterine Leiomyomas. J Obstet Gynaecol Can 37(2): 157-178.

16. Aharoni A, Reiter A, Golan D, Paltiely Y, Sharf M (1988) Patterns of growth of uterine leiomyomas during pregnancy. A prospective longitudinal study. Br J Obstet Gynaecol 95(5): 510-513.

17. Rosati P, Exacoustòs C, Mancuso S (1992) Longitudinal evaluation of uterine myoma growth during pregnancy. A sonographic study. J Ultrasound Med 11(10): 511-515.

18. Ciavattini A, Di Giuseppe J, Stortoni P, Montik N, Giannubilo SR, et al. (2013) Uterine fibroids: pathogenesis and interactions with endometriumand endomyometrial junction. Obstet Gynecol Int 2013: 173184 .

19. Klatsky PC, Tran ND, Caughey AB, Fujimoto VY (2008) Fibroids and reproductive outcomes: a systematic literature review from conception to delivery. Am J Obstet Gynecol 198(4): 357-366.

20. Exacoustòs C, Rosati P (1993) Ultrasound diagnosis of uterine myomas and complications in pregnancy. Obstet Gynecol 82(1): 97101.

21. Mollica G, Pittini L, Minganti E, Perri G, Pansini F (1996) Elective uterine myomectomy in pregnant women. Clin Exp Obstet Gynecol 23(3): 168-172.

22. De Carolis S, Fatigante G, Ferrazzani S, Trivellini C, De Santis L, et al. (2001) Uterine myomectomy in pregnant women. Fetal Diagn Ther 16(2): 116-119.

23. Wittich AC, Salminen ER, Yancey MK, Markenson GR (2000) Myomectomy during early pregnancy. Mil Med 165(2): 162-164.

24. Glavind K, Palvio DH, Lauritsen JG (1990) Uterine myoma in pregnancy. Acta Obstet Gynecol Scand 69(7-8): 617-619.

25. Michalas SP, Oreopoulou FV, Papageorgiou JS (1995) Myomectomy during pregnancy and caesarean section. Hum Reprod 10: 1869-1870.

26. Febo G, Tessarolo M, Leo L, Arduino S, Wierdis T, et al. (1997) Surgical management of leiomyomata in pregnancy. Clin Exp Obstet Gynecol 24(2): 76-78.

27. Celik C, Acar A, Ciçek N, Gezginc K, Akyürek C (2002) Can myomectomy be performed during pregnancy? Gynecol Obstet Invest 53(2): 79-83.

28. Saccardi C, Visentin S, Noventa M, Cosmi E, Litta P, et al. (2014) Uncertainties about laparoscopic myomectomy during pregnancy: A lack of evidence or an inherited misconception? A critical literaturereview starting from a peculiar case. Minim Invasive Ther Allied Technol 24(4): 189-194.

\section{Your next submission with Juniper Publishers} will reach you the below assets

- Quality Editorial service

- Swift Peer Review

- Reprints availability

- E-prints Service

- Manuscript Podcast for convenient understanding

- Global attainment for your research

- Manuscript accessibility in different formats

( Pdf, E-pub, Full Text, Audio)

- Unceasing customer service

Track the below URL for one-step submission https://juniperpublishers.com/online-submission.php 